\title{
Making the most of little water
}

\section{Rehovot}

RAIN-making has come of age in Israel. Starting in October, immediately after the Feast of Tabernacles, religious Jews have traditionally prayed for rain and dew in the Holy Land. Two generations ago in Jerusalem, Sephardic Chief Rabbi Avraham Gagin led the prayers, and now his grandson, a Hebrew University meteorologist also named Avraham Gagin, is Israel's chief rainmaker.

Professor Gagin and his colleagues claim that cloud seeding has achieved an annual increase of precipitation of approximately 15 per cent. Two basic methods are used. The first is to seed clouds from light aircraft with silver iodide particles - carried in vapourized acetone. There is also a supplementary system using cannon-like generators strategically located in the mountainous northern part of the country which can discharge silver iodide particles into the sky when the appropriate clouds are present.

The ability of Israeli meteorologists to determine exactly which clouds to seed, as well as their exhaustive statistical and physical studies of the results of seeding programmes, have brought many requests for guidance. This month, for example, Professor Gagin will fly to Mexico to talk to rainmakers there. And although Israel's Arab neighbours might have objected to cloud seeding as a means of "stealing their rain", Israeli efforts have in fact increased rainfall in neighbouring Jordan.

Conservation nevertheless remains the backbone of Israeli concern for water supply, and attention is focused on agriculture since more than 80 per cent of local water still goes to farmers. Dr Gerald Stanhill of the Volcani Agricultural Research Centre says that the water delivery and irrigation systems now used in Israel ensure that four-fifths of the water allocated for irrigation actually passes through the crops under cultivation, contributing to their growth and yield. This contrasts with a world average of less than 50 per cent.

The hallmark of Israeli practice is that water reaches the fields in closed pipes instead of through canals and ditches which are prone to seepage and evaporation and because, being under pressure, it can be applied exactly where and when required. Drip irrigation, a system developed in Israel whereby water sometimes mixed with chemical fertilizers and even pesticides - reaches individual plants through perforated plastic pipes (rather than being spread over an entire field as with other irrigation systems), also saves water.

A refinement of this system is now being tried out by Dr Israel Levin, a kibbutznik attached to the Volcani Centre, who is using plastic pipes not on the surface but about $40 \mathrm{~cm}$ below ground level. The tendency for the little holes in the pipes to be clogged by the roots of the plants under cultivation has been overcome by adding a herbicide to the water, which kills the roots of the plants around the holes without affecting roots elsewhere.

Fertilizer supplied through the irrigation system (known as fertigation) is especially effective in orange groves, according to $\mathrm{Dr}$ Hanoch Bielorai and his colleagues at the Volcani Centre. They say that fertigation can increase yields by as much as a third and, because the system is more selective, economize in fertilizer and thus minimize the danger of ground water being polluted by nitrogen.

In the spirit of making every drop of water count, another Volcani research group headed by Dr Yehezkiel Cohen is individually metering the quantity that passes through single trees or even single plants. Using heat pulses in the trunk or stem as flowmeters, they can directly measure water requirements and so adjust the irrigation programme accordingly.

Dr Stanhill and his Volcani colleague Dr Ehud Stibbe are particularly concerned with the energy cost of Israel's sophisticated water-supply system. They point out that moving water from one place to another under pressure requires a great deal of energy and that piping water to farms under lower pressure requires less fuel.

Conservation would also be served, says Professor Dan Yaron of the Hebrew University's faculty of agriculture, if farmers were charged a more realistic price for water. Such a move might even eliminate production of certain water-intensive export crops which are now sold at a loss to the national economy. Professor Yaron points out that a decline in the demand for water would eliminate the need to develop new resources, "which is increasingly expensive because easily exploitable sources have long since been harnessed". The money saved, in Yaron's view, could be used for other development projects that might bring greater benefits to rural areas.

Nechemia Meyers

\section{Search for improvement begins}

Australian technology

\section{Canberra}

THE new Australian Government is setting great store by technology. In a speech at the opening of the national technology conference last month, the Prime Minister, $\mathrm{Mr}$ Bob Hawke, for the first time saw new technology as playing a central rather than a peripheral role in a strategy for economic recovery. "Industrial innovation is essential to Australia's future economic wellbeing, not only in industries producing glamorous new products, but throughout established industries as well." This was Mr Hawke's strongest statement yet in support of the stand taken by his Minister of Science and Technology, Mr Barry Jones, who has long been cajoling and admonishing a recalcitrant nation to sit up and take notice. The Prime Minister's remarks contrast with the view expressed by his cabinet only a few months ago, before the April economic summit, that a paper by Mr Jones was "too alarmist" to be presented on that occasion.

Mr Jones's opening speech last month, based on that ill-fated paper, was largely a reiteration of his familiar theme. "Australia has become an industrial museum and our factories are working models of the age of chisels, spanners and hammers ... Managers and investors are often unaware of the technological and research capacity that surrounds them." He pointed out that Australia, with 0.3 per cent of the world's population, produces 2.0 per cent of its scientific papers but ends up with only 0.1 per cent of the world's high technology output and ranks twentysecond out of the 24 nations of the
Organization for Economic Cooperation and Development (OECD) in per capita exports of technology-intensive products.

Bringing together academics, captains of industry, trade unionists, bureaucrats and politicians, the conference organizer - the Department of Science and Technology posed specific questions to groups of participants to establish agreement on how to draft a "national technology strategy". Consensus, however, was noticeably lacking on key issues such as the need for selective assistance to specific "sunrise" industries, or on what needs to be done about the employment-displacing effect of new technology. There was agreement only on topics over which there can be no dispute - the private sector ought to invest more in research and development, companies must revitalize themselves by adopting new technology, education is important and there should be greater interaction between research institutions.

One contribution at the conference was the suggestion that any subsidiary of an overseas company established locally should be completely autonomous with regard to investment and management decisions and the Foreign Investment Board should try to insist on this.

Unusually, this conference did not break up on a self-congratulatory note. Mr Jones made clear in his closing address that he was dissatisfied with the outcome and despaired of reaching consensus in time to make effective technology policy. "The sleepers may be waking, but they are still very drowsy" he concluded, in an allusion to his book Sleepers, awake. Vimala Sarma 